Arab World English Journal (AWEJ) Volume 12. Number1 March 2021

Pp.443-457

DOI: https://dx.doi.org/10.24093/awej/vol12no1.29

\title{
The Latest Tools for the Formation of Foreign Language Communicative Competence of Students of Non-language Specialties
}

\author{
Olha Turko \\ Pedagogy and Psychology Department \\ Ternopil V. Hnatiuk National Pedagogical University, Ukraine \\ correspondent Author: olha.turko@gmail.com \\ Tetiana Kravchuk \\ Foreign Language Department \\ Ternopil V. Hnatiuk National Pedagogical University, Ukraine \\ Oleksandra Kashuba \\ Foreign Language Department \\ Ternopil V. Hnatiuk National Pedagogical University, Ukraine \\ Halyna Navolska \\ Foreign Language Department \\ Ternopil V. Hnatiuk National Pedagogical University, Ukraine \\ Ivan Kutsyi \\ Historical Department, \\ Ternopil V. Hnatiuk National Pedagogical University, Ukraine
}

Received: 12/13/2020

Accepted: 3/10/2021

Published: $3 / 24 / 2021$

\section{Abstract}

This paper aims at demonstrating the effectiveness of modern methods of formation of English language communicative competence of those students who study at non-language specialties. The experimental work was carried out at the Faculty of Pedagogy and Psychology, the Faculty of Physical Education and the Faculty of History of Ternopil National Pedagogical University named after Volodymyr Hnatyuk, Ukraine. The authors present their experience of conducting a three-year-long training using game technology, project-based technology, interactive technologies, tasks in the electronic system Moodle, etc. and discuss the benefits of using those means at university. The core question of the given study is whether these means are effective in the formation of students' foreign language communicative competence. The authors demonstrate the benefits of studying with the help of modern lingua-didactic and technical means. The results of the survey indicate that these tools are effective in their integrated application for the formation of English language skills. To conclude, the findings of the study can be applied while teaching English to the students of non-language specialties.

Keywords: electronic source, foreign language communicative competence, game technology, innovative forms and methods of work, interactive teaching, project-based technology, student-centered learning

Cite as: Turko, O., Kravchuk, T., Kashuba, O., Navolska, H., \& Kutsyi, I. (2021). The Latest Tools for the Formation of Foreign Language Communicative Competence of Students of Non-language Specialties. Arab World English Journal, 12 (1) 443-457 .

DOI: https://dx.doi.org/10.24093/awej/vol12no1.29 


\section{Introduction}

Language of the functioning of a developed progressive society is a suitable means of understanding, expressing and interpreting notions, facts, feelings, thoughts both orally and in written form. Language is an integral part in boosting individual potential and development, expanding person's employment possibilities, social integration and active citizenship. At the same time, intensive expansion of Ukraine's international relations and its active involvement to the world of foreign languages have caused increased attention to academic mobility as a factor in the country's integration into the scientific and educational world. Academic mobility is available and effective if there is knowledge of a foreign language as a means of communication, knowledge of foreign culture, education, professional realization.

It is quite natural that these factors cause the priority of communicative competence among dominant competences of the $21^{\text {st }}$ century for lifelong learning in the world (ANNEX, 2018) and in the Concept of the New Ukrainian School (Bibik, 2017), which has become the basis for all students of general secondary education in Ukraine.

At the same time, there is a growing interest in forming communicative competence as both national and foreign language ability of social, personal and educational interaction.

The formation of foreign language communicative competence of future teachers is a sign of their professionalism. Knowledge of a foreign language allows you to communicate with colleagues from abroad, to study the scientific experience of other countries. Both foreign language teachers and students face a difficult problem. The process of language acquisition for Ukrainian-speaking students is quite complex, as their native language (Ukrainian) and foreign language (English) are not genetically related. Foreign students also have problems learning the Ukrainian language.

The purpose of this article is to describe the experience of using tools (game technology, project-based technology, interactive technology, tasks in the electronic system Moodle, etc.) in the formation of foreign language communicative competence of bachelor students in nonphilological specialties.

The tasks of the article:

1) to analyze the scientific literature on communicative competence;

2) to define communicative competence;

3) to experimentally identify the effectiveness of game technology, project-based technology, interactive technology, tasks in the electronic system Moodle, etc. in teaching English to the students of non-language specialties.

\section{Literature Review and Theoretical Background}

The notion "communicative competence" is one of the most critical scientific categories the study of which began in the $60-70 \mathrm{~s}$ of the $20^{\text {th }}$ century. A signicant amount of research work has already been dedicated to this problem. Scientists point out the importance of defining this notion as "the representatives of different spheres describe this term taking into consideration their interests and dwell upon its most essential components as relevant to this or that sphere" (Barton \& Haydn, 2006, p. 261). 
The term "communicative competence" (from Latin community - make general, connect, communicate and competent (competent) - able) means the summation of knowledge about norms and rules of leading a natural communication such as dialogue, conflict, negotiations, etc. (Beh, 1998). Communicative competence is the basis of education using both the means of a native and foreign language.

Nowadays there is a large amount of research dedicated to this problem. At the same time, scholars constantly point to the exceptional importance and accuracy of the definition of this term, "because the representatives of various fields of knowledge describe this concept from the standpoint of their interests and emphasize what is essential for this science" (Hez, 1985, p. 17).

The American linguist N. Chomsky first introduced the term "competence" into scientific usage in 1965. The scientist noted that the fundamental difference between competence (knowledge of one's language by a speaker) and usage (actual use of language in specific situations) is that competence can be represented in the form of a set of knowledge, skills, abilities acquired by students during training, and the application of acquired knowledge, skills, abilities is the content of the student's competence: his/her ability to perform a speech act based on established competence (Chomsky, 1972). In Slavic lingua-didactics, the term "communicative competence" was first introduced by M. Vyatutnev. The scientist defined communicative competence as follows: "the choice and implementation of a program of speech behavior, which depends on a person's ability to navigate in communication situations and the ability to classify situations depending on the topic, tasks and communicative guidelines" (Vatuitniev, 1977, p. 39).

Studies of the scientific literature on the meaning and essence of communicative competence show two approaches to defining the closest generic concept about communicative competence. Some authors explain communicative competence with the help of the idea "ability" and view it as the ability to use the language in a specific sphere of communication (Izarenkov, 1990; Savignon, 1995; Vatuitniev, 1977; etc.).

The representatives of the second approach define communicative competence through the prism of such concepts as "knowledge," "skills" and "abilities" (Fedorenko, 2002; Hez, 1985; Hymes, 1966; Kazartseva, 1999; etc.).

Consequently, communicative competence appears as a structural phenomenon that contains such components as values, motives, attitudes, socio-psychological stereotypes, knowledge, skills, abilities.

Nowadays scientists and instructors define communicative competence as the ability of the person to apply the language knowledge in a definite situation, ways of interaction with the surrounding and distant people and events, skills of group cooperation, knowing various social roles.

Communicative competence belongs to the group of critical notions, has a specific role in a person's life. Thus one must pay special attention to its formation. 
Firstly, this feature influences the level of performance. The simplest example: if a student is shy to answer in front of the group or feels extremely worried, his/her answer will be worse than the possessed knowledge, and his/her mark, consequently, will be lower. The obtained negative experience will influence the further studying of a student in a wrong way.

Secondly, the process of student's adaptation to studying in an educational establishment, mainly his/her emotional wellbeing, among other students depends on communicative competence in lots of ways. Transformation, as we all know, is divided into educational and social-psychological. A student must get used to studying and to the people around. If it is easy for him/her to find common ground with group mates, he/she feels psychological comfort and pleasure. At the same time the inability to communicate with peers makes the circle of friends smaller, causes the feeling of solitude and can provoke asocial forms of behavior.

Thirdly, students' communicative competence can be viewed in an educational process as the resource of effectiveness and wellbeing in his/her future professional life (Bodnar, 2007).

There are the following components of communicative competence:

- orienting in various situations of communication which is based on knowledge and personal experience;

- the ability to effectively cooperate with the surrounding thanks to the understanding of yourself and others in constant change of psychic states, interpersonal relations and conditions of social surrounding;

- adequate orientation of a person in oneself - own psychological potential, partner's potential and situation;

- readiness and ability to build contacts with people;

- inner means of regulation of communicative actions;

- knowledge, skills and skills of constructive communication;

- internal resources necessary for the construction of effective communication in definite situations of interpersonal interaction.

The development of foreign language communicative competence require

- define the notion and structure of competence and also the essence on other stages of life;

- apply systemic approach, ensure the cooperation between different participants, directions and techniques to get a result;

- choose a method, make a program, directions, technologies and techniques of developing students' communicative competence.

There are three closely connected dimensions of verbal communicative competence: thematic, proactive, practical-value-based (See Table one) (Lomakovytch et al., 2011). Table 1. Dimensions of verbal communicative competence

\begin{tabular}{|l|l|l|}
\hline Dimension & Formed property & Cognitive level \\
\hline Thematic & $\begin{array}{l}\text { Acquiring the subject about the language } \\
\text { and speech foresees the demonstration of } \\
\text { awareness in different science spheres }\end{array}$ & $\begin{array}{l}\text { Knowledge (operating the } \\
\text { terms and facts in different } \\
\text { spheres concerning language }\end{array}$ \\
\hline
\end{tabular}




\begin{tabular}{|c|c|c|}
\hline & concerning language and speech. & and speech). \\
\hline Proactive & $\begin{array}{l}\text { Mastering different types of activities with } \\
\text { language and speech units. Ability to } \\
\text { operate with language units in } \\
\text { communication in accordance with the } \\
\text { communicative purpose and based on } \\
\text { knowledge of the laws and principles of } \\
\text { the language system. }\end{array}$ & $\begin{array}{l}\text { Abilities (capability to carry } \\
\text { out communicative actions, } \\
\text { mainly such as reading and } \\
\text { writing). }\end{array}$ \\
\hline $\begin{array}{l}\text { Practical- } \\
\text { value-based }\end{array}$ & $\begin{array}{l}\text { Demonstration of the ability to conduct } \\
\text { verbal communication to achieve goals } \\
\text { that are relevant and valuable to man, } \\
\text { society and humanity in accordance with } \\
\text { the values of a society of sustainable } \\
\text { development. }\end{array}$ & $\begin{array}{l}\text { Value-based attitude to speech } \\
\text { as the main means of } \\
\text { communication in all spheres } \\
\text { of activity (understanding the } \\
\text { role of language and } \\
\text { communication in man and } \\
\text { society, the use of language } \\
\text { knowledge and } \\
\text { communication skills to solve } \\
\text { practical problems). }\end{array}$ \\
\hline
\end{tabular}

The following instructor's tasks in the formation of students' communicative skills have been formulated taking into consideration verbal-communicative competence:

- to ensure the language environment for students: listening to instructors' speech, reading books, listening;

- to make sure communicative situations are created and students have communicative practice;

- to guarantee the students' acquisition of lexical units, grammar forms, syntactic constructions, logical connections; to activate the use of vocabulary units and grammar constructions; to ensure that all necessary abilities in the sphere of speech development are formed;

- to conduct constant work connected with the language development and professional fieldrelated classes (Pedagogics, Psychology, History) while practicing students' skills in grammar, vocabulary, reading, listening;

- the atmosphere of fight for the high level of communication, for the implementation of demands concerning the speech correctness.

There are such details in the structure of communicative competence:

- cognitive,

- value-based notional,

- personal,

- emotional,

- behavioral. 
They are not a part of the whole, but they presuppose inter influence and the existence of each of them which means:

- the essence of a separate component is revealed through others, relates with them;

- all the components must be included in the work;

- the components which aim at the student's development in all the stated directions are considered to be more effective.

Cognitive component makes up the knowledge about value-based sides of transmission, about personal qualities which help and interfere with communication, about emotions and feelings which always accompany it, about operational (behavioral) sides of communication.

Value-based component consists of values that are activated in communication.

Student's communicative competence must be based on confidence, optimism, kind treatment and respect to people, justice, altruism, frankness, emotional stability, lack of aggressiveness, absence of conflicts.

The emotional components of communicative competence are related to the creation and maintenance of positive emotional contact with the interlocutor, self-regulation, the ability not only to respond to the changes in the state of the partner, but also to anticipate them. The emotional temperature creates the feeling of psychologically fortunate or unfortunate, comfortable or uncomfortable communication.

Behavioral component consists of communicative skills, ways of action and experience which integrates all the manifestations of communicative competence. Communicative skills as elements create communicative behavior. Their peculiarities and the level of formation can be studied and measured and can also become definite tasks in students' development and correction.

The organization of communication is the most crucial aspect for the formation of foreign language communicative competence.

Parchin believes that communication is a complex multi-layered process, which can also be a process of human interaction, exchange of information. In addition, communication is how people treat each other, the process of their influence on each other, how they experience each other and understand each other (Hez, 1985).

There are three sides in the structure of communication: communicative, interactive and perceptive.

Communicative side of communication is the information exchange and its understanding.

Interactive side of communication consists of the interaction between partners. Here we distinguish:

- collaboration;

- confrontation;

- evasion from cooperation. 
Perceptive side of communication takes place when partners perceive each other while communicating. It depends on personal qualities of the person who perceives his/her personal experience, moral values, situations of interaction, etc.

Speech culture plays a vital role in foreign language communicative competence.

Speech culture takes place when people adhere to the set norms of oral and written literate language. When they consciously and brilliantly use language means depending on the aim and conditions of communication.

The following criteria of speech culture are defined:

- communication object-matter (connected with specific aim, important information, valuable idea, etc.);

- logics - consistency, validity, absence of repetitions, absence of anything inappropriate, presence of findings which come from the expressed points. Logically correct address must have appropriate conclusions (if any), presupposes the ability not only to start but also to finish the utterance;

- accuracy is connected not only with the ability of a speaker to convey exact facts, observations and feelings, but also to choose the best language means for doing that;

- abundance of address presupposes the use of various language means, the ability to choose the words appropriate to the situation;

- expressiveness is the ability to convey the thoughts in a bright, persuasive and concise way; this is the ability to influence people with the help of intonation, by choosing facts, making appropriate constructions, by the mood of one's utterance;

- purity of address deals with the absence of filler words, dialect words, etc.;

- correctness of speech is the correspondence to literate norm; one distinguishes between grammatical, orthographic, punctuational (for the written speech) and orthoepic (for the oral speech);

- communicativeness presupposes accessibility to those people to whom it is directed. Any speech has addressee. When writing or speaking, one must take into consideration intellectual potential, interest, the level of education, age peculiarities of the person the speech is aimed at.

Communication is always motivated. Nevertheless, studying the motive is not always present. It is necessary to create conditions thanks to which students will have a wish and necessity to say something, express their feelings in a suggested setting. One must create comfortable psychological conditions during the classes, enhance friendly relations, interest in the work which will keep the students interested in what they do.

Situational character is one of the most vital peculiarities of speech. Moreover, situations can be defined by person's social status, activities and role as a subject of speech. When teaching students to communicate, it is necessary to use all the possible kinds of activities to develop vocabulary. This principle is realized by the character of an imaginary communicative situation.

One of the components of communicative competence is the ability to understand and overcome communicative barriers which can arise, for example, when there is lack of understanding of the situation. There are misunderstandings between partners (social, political, religious, professional which cause different ways of interpreting and are connected with 
ideology and our vision of world). The barriers in communication can have psychological character reflecting individual psychological peculiarities of those who communicate, reflecting their current views: ranging from friendship to hostility towards each other.

Summing up, the described ideas are essential for testing the effectiveness of innovative means of forming foreign language communicative competence of students.

The most essential means in students' foreign language communicative competence formation were interactive approach (interactive classes, interactive methods of education), remote forms of teaching (electronic distant learning system Moodle), student-centered learning, problembased learning, games, etc.

Interactive approach can be explained as the ability to interact while having a conversation, dialogue. Consequently, one can view a method as interactive when the person who studies is a participant who does something: speaks, manages, models, writes, paints; thus he/she is not only a listener, but also takes an active part in what is going on being an active participant of the studying process. Interactive teaching happens when an instructor using a particular system of approaches, methods, techniques based on equal subject-subjective relations of a teacher and student organizes the educational process using communication, self-assessment, positive feedback, constant students' activeness (Hryshchuk, 2014). Interactive teaching is precious as students are taught do the work effectively in a group. Interactive methods are part of studentcentered approach and they help students to perceive themselves as a part of a group, to understand their role and potential. Working in pairs turned out to be influential among all interactive technologies. One of the advantages of this technology is the fact that all students have the opportunity to exchange views with their partners and only then express them to the whole group. These are the attempts not only to be heard but also to learn to listen to others. The following are the examples of such work: discussing the text, making sentences using the given parts (as a puzzle), making rules and pieces of advice, checking the performed tasks of each other. Working in small groups students get a chance to communicate, compare, express the thought freely, make common conclusions.

Project-based method has also increased the level of communicative competence among students. Working on projects students learn to think critically and to realize where and how they can apply the knowledge, to generate new ideas, use information appropriately, be sociable and work constantly on self-perfection.

Distant learning system Moodle helped check the obtained knowledge; this platform united instructors and students into one integrated system for creating personalized educational environment. Thanks to this electronic system students did the tests individually, wrote essays, chatted online. They had the chance to see test results right after finishing them. Besides, they could be consulted on all the questions either in Moodle chat communicating with the instructor or using this platform for the answers they needed (all the necessary information and the list of recommended sources were put on the system by the instructor).

Games foster unconstrained communication of students with the group. While playing a game one's imagination develops, the images of one's fantasies and ideas settle, products of activity are created, they are emotionally attractive for students. Games are crucial as they give students 
an opportunity to dream and show their imagination; games make the platform for creativity, leadership skills and responsibility. Everything mentioned is an excellent source for enriching students' vocabulary and developing communicative qualities.

Communicative situations are among the most essential means of forming students' communicative competence; they stimulate active mental activity and make students express their thoughts using a foreign language.

Situation is a basis of such tasks. It deals with the conditions of communication; the relations of that person who is talking to that person who is listening; general direction of the utterance. A situation in which a person talking because of his/her desire and need is called a communicative situation. If a teacher pushes a student to communication, the situation is stimulating.

Communicative situations appear by themselves in a natural process of communication. These are the so-called natural situations. Artificial situations are a reflection of external conditions and are aimed at dialogic communication, when students express their thoughts and emotions.

One of the main features of communicative situations is the presence of a speech stimulus, which arises student's speech reaction and determines the choice of this or that speech unit.

\section{Methods \\ Participants}

300 bachelor students of non-philological specialties (Faculty of Pedagogy and Psychology, Faculty of Physical Education, Faculty of History) of Ternopil National Pedagogical University named after Volodymyr Hnatiuk took part in this empirical study. The experimental study was conducted during the 2016-2017, 2017-2018 and 2018-2019 academic years. The participants were divided into two experimental groups.

\section{Apparatus and Materials}

Experimental learning resources consisted of 1) tests for students' independent acquisition of linguistic knowledge during their extracurricular activities and 2) professional methodological functions and activities using various teaching methods and technologies (game method, projectbased technology, interactive technologies, tasks in the electronic system Moodle, etc.). The training materials were taken from various training sources (see training materials: Grammar Way, 2016; SpeakOut).

\section{Procedure}

The experimental study included the identification and rethinking of research problems. Next, we formulated a hypothesis, and organized an experiment. Then we analyzed the data, made statistical calculations and formulated conclusions. In the end, tested the hypothesis, formulated conclusions.

The ascertaining stage comprised the studying of the problems in pedagogical theory, and practice; the analysis of psychological, psycho-linguistic and scientific-methodical literature in terms of the given sphere; research tasks were defined; the students in control and experimental groups showed the level of foreign language communicative competence which was almost the same in both groups. 
At the formal stage, students of the experimental group were taught using innovative techniques. The students of the control group were taught in the traditional way.

During the summarizing stage control tests were conducted to check the efficacy of the used methods of education; qualitative-quantitative analysis of the research results was performed; the effectiveness of the applied approaches to teaching in foreign language communicative competence formation was defined.

The levels of methodological knowledge and skills among the participants were measured by the formula $\mathrm{K}=\mathrm{A} / \mathrm{N}$, where $\mathrm{K}$ is the coefficient of learning outcomes, $\mathrm{A}$ is the number of points obtained for correct answers, and $\mathrm{N}$ is the maximum number of points assigned for correct answers (Bespalko, 1968). Learning outcomes of 0.7 and above were considered acceptable according to Cronbach's alpha reliability factor (Cronbach, 1951).

\section{Results}

The experimental research was carried out thanks to the students of such faculties: Pedagogics and Psychology, Chemistry and Biology, Physical education, History. Ukrainian as a native language and English or German as foreign languages are not field-specific for those students.

Functions of Communicative Situations:

1) orientation to the stage of forming author's intention: facilitate the desire to utter; arouse a visual picture about the addressee;

2) situations which lead students to the place where thoughts appear: stimulate the process of creating monologue, dialogue; need constructive activity with the elements of creativity; program the construction of own creative free utterances (collective, group, individual).

The aim of communicative situations is to urge students to solve different aspects of communication with language means. A teacher collects a bank of facts while making communicative situations. The "Bank of Facts" is a collection of unusual cases that can be turned into tasks.

There are permanent communicative situations: reporter, author, leader, pessimist, optimist, skeptic, famous person, famous book characters. Thus, the tasks of the communicative situation emphasize the communication situation, name all its components (topic, purpose, addressee, conditions, etc.).

One of the most effective means of influencing students' communicative competence is the usage of a system of cognitive tasks the basis of which is the performance of intellectual actions: analysis, synthesis, comparison, generalization, analogy, classification. The conduction of nonstandard classes fosters the formation of communicative competence.

The types of classes can be various: disputes, conferences, research, etc.

Research classes create conditions for individual work of students in learning material thanks to the development of intellectual abilities. Mainly, the ability to operate information individually obtained from different sources, present information in a precise or detailed way. Such classes have some peculiarities: a) students get new knowledge in the process of individual work; b) students learn to apply this knowledge, skills, abilities in different problems; c) students 
construct and solve such situations which require creative approach, individual work and corresponding emotional state.

Classes-reports are held at the end of semester (academic year) with the aim of checking students' knowledge and skills in one or several topics. New pedagogical thinking requires preparation and conducting classes in the center where there should be separate students, micro groups or whole groups. A teacher in such an academic process is a helper. Such non-standard classes are based on the trust and support of students' learning efforts. The program is planned. Students or a teacher choose an announcer, emcee, journalists, opponents, academic board, etc. The topic is related to a field of study, for example, "Perennial plants", "Ukraine in Cossacks' era." It is vital to keep to lexical and grammatical speech correctness. Such classes are critical: revision of the learned material and widening students' outlook. They also foster creativity, thinking, speech, the ability to communicate, bring up speech culture.

Classes-discussions consist of classes-dialogues, classes-disputes, classes-court trials, etc. Such classes are held after learning a specific topic to deepen and systematize students' knowledge. Classes-discussions can result from students' previous research work, individual study of specialized literature on a definite issue. Such classes give a possibility to see different positions concerning a complex problem, involve students to active work, foster the development of their interests, enrich vocabulary which is necessary. Classes-discussions deepen the experience in communication since special attention is paid to the formation of such skills as asking and relying.

Interactive technologies, Moodle, student-centered teaching which were implemented in the experimental group helped to increase foreign language communicative competence of students. Students in experimental group were much better at performing suggested tasks than the students in control group (see Table two).

Table 2. Level of students' foreign language communicative competence in control and experimental groups at the beginning of research

\begin{tabular}{|c|c|c|c|c|c|}
\hline \multirow{3}{*}{$\begin{array}{l}\text { Development of } \\
\text { communicative skills }\end{array}$} & \multirow{3}{*}{$\begin{array}{l}\text { Speech } \\
\text { deviation }\end{array}$} & \multicolumn{4}{|c|}{ Groups } \\
\hline & & \multicolumn{2}{|c|}{ control group } & \multicolumn{2}{|c|}{ experimental group } \\
\hline & & $\%$ & $\begin{array}{l}\text { number of } \\
\text { students }\end{array}$ & $\%$ & $\begin{array}{l}\text { number of } \\
\text { students }\end{array}$ \\
\hline \multirow{2}{*}{ Speech norms adoption } & $\begin{array}{l}\text { orthoepic } \\
\text { correctness }\end{array}$ & $17 \%$ & 28 & $20 \%$ & 30 \\
\hline & $\begin{array}{l}\text { grammatical } \\
\text { correctness }\end{array}$ & $19 \%$ & 29 & $19 \%$ & 28 \\
\hline \multirow{3}{*}{$\begin{array}{l}\text { Formation of the skills } \\
\text { of active work with a } \\
\text { word }\end{array}$} & speech accuracy & $25 \%$ & 37 & $21 \%$ & 31 \\
\hline & speech purity & $19 \%$ & 29 & $21 \%$ & 32 \\
\hline & speech abundance & $18 \%$ & 27 & $19 \%$ & 29 \\
\hline $\begin{array}{l}\text { Mid-point of errors } \\
\text { competence }\end{array}$ & foreign language & $19,6 \%$ & & $16,6 \%$ & \\
\hline
\end{tabular}


Analyzing the results provided in the table we can conclude a low level of the formation of students' foreign language communicative competence in both control and experimental groups.

The second stage of research consisted of the approbation of creative means of communicative competence development.

The works of students of both groups were analyzed during and after the research. The results show that there have been positive changes in the formation of communicative competence among the students in experimental group. The number of errors (both in oral and written speech) has decreased among the students of experimental group (see Table three).

Table 3. Level of students' foreign language communicative competence in control and experimental groups after research

\begin{tabular}{|c|c|c|c|c|c|}
\hline \multirow{3}{*}{$\begin{array}{l}\text { Development of } \\
\text { communicative skills }\end{array}$} & \multirow{3}{*}{$\begin{array}{l}\text { Speech norms } \\
\text { deviation }\end{array}$} & \multicolumn{4}{|c|}{ Groups } \\
\hline & & \multicolumn{2}{|c|}{ control group } & \multicolumn{2}{|c|}{ experimental group } \\
\hline & & $\%$ & $\begin{array}{l}\text { number of } \\
\text { students }\end{array}$ & $\%$ & $\begin{array}{l}\text { number of } \\
\text { students }\end{array}$ \\
\hline \multirow{2}{*}{ Speech norms adoption } & $\begin{array}{l}\text { orthoepic } \\
\text { correctness }\end{array}$ & $19 \%$ & 29 & $8 \%$ & 12 \\
\hline & $\begin{array}{l}\text { grammatical } \\
\text { correctness }\end{array}$ & $21 \%$ & 32 & $8 \%$ & 12 \\
\hline \multirow{3}{*}{$\begin{array}{l}\text { Formation of the skills } \\
\text { of active work with a } \\
\text { word }\end{array}$} & speech accuracy & $17 \%$ & 26 & $9 \%$ & 13 \\
\hline & speech purity & $19 \%$ & 28 & $9 \%$ & 14 \\
\hline & $\begin{array}{l}\text { speech } \\
\text { abundance }\end{array}$ & $23 \%$ & 35 & $5 \%$ & 8 \\
\hline \multicolumn{2}{|c|}{$\begin{array}{l}\text { Mid-point of errors in foreign language } \\
\text { competence }\end{array}$} & $19,8 \%$ & & $7,8 \%$ & \\
\hline
\end{tabular}

The third table shows that the level of deviations in foreign language communicative competence among the students in experimental group has decreased.

The purpose of research work was to test the effectiveness of game technology, project-based technology, interactive technologies, Moodle, personality-oriented learning, etc., aimed at forming foreign language communicative competence of students of non-philological specialties.

Only 59 students out of 150 students in experimental group had deviations in some speech norms indicators. 91 students $(61 \%)$ showed the formed foreign language communicative competence which proves the methodological effectiveness of the applied innovative teaching means.

\section{Discussion}

We have completed all the tasks of the article:

1) analyzed the scientific literature on communicative competence; 
2) defined communicative competence;

3) experimentally found the effectiveness of game technologies, design technologies, interactive technologies, tasks in the electronic system Moodle, etc. in teaching English to students of non-language specialties.

The diagnosis of the English language competence after the use of innovative teaching aids (interactive technologies, Moodle, student-centered learning) showed that students improved their products.

The following conclusion is interesting: learning tools determine the result, not the learning material. Students of the control group and the experimental group studied using the same material. Students had different results through teaching aids.

Interestingly, the level has improved in both language and speech skills. Students' vocabulary has expanded, grammar knowledge has improved, and so on.

Students of the control group mastered the same phonetic, lexical, grammatical material. We checked reading, talking, writing, listening. We worked with these students using a single textbook and homework notebook. Methods of work: checking new words, constructing sentences, reading new texts and their translation, questions to the test, etc.

We noticed that the students of the control group began to lose interest in classes after several months of study.

Instead, the students of the experimental group showed more interest in English classes: they asked questions, wanted to study even during breaks, actively communicated with each other in English.

There are several implications derived from this study. Firstly, game technology, projectbased technology, interactive technologies, Moodle, personality-oriented learning, etc. have improved language competence of students of non-language specialties. It is necessary to study how these tools will affect the study of a foreign language by the students of the Faculty of Foreign Languages.

Secondly, the question arises as to which of these tools are effective in distance learning.

Thirdly, we plan to determine the effectiveness of technical means of teaching and illustrations in the formation of foreign language communicative competence formation. Technical teaching aids have become relevant in the context of distance learning caused by the incidence of COVID-19.

\section{Conclusion}

The results of the study will contribute to the development of communicative competence of bachelors, social adaptation, speech culture, development of critical thinking. The results can also be helpful for other academic institutions, improving the content of teaching in various fields and outlining new methodological areas for the development and conduct of foreign language classes. 


\section{About the Authors \\ Olha Turko is a Lecturer of Pedagogy and Psychology at Ternopil V. Hnatiuk National} Pedagogical University, Ukraine. She got her PhD (Candidate of Philological Sciences). Her scientific interests are higher education, foreign language teaching methods, syntax, linguodidactics. ORCID ID: https://orcid.org/0000-0002-4178-0483

Olha Turko (0000-0002-4178-0483) orcid.org

Zolotogorska str., 8/20, Ternopil, 46012, Ukraine, olha.turko@gmail.com

Tetiana Kravchuk is a Lecturer of Foreign Language at Ternopil V. Hnatiuk National Pedagogical University, Ukraine. She got her PhD (Candidate of Philological Sciences). Her scientific interests are higher education, foreign language teaching methods, German as a Second Language. ORCID ID https://orcid.org/0000-0003-1396-4573

Kravchuk Tetiana (0000-0003-1396-4573) orcid.org

Kulisha str. 4/54, Ternopil, 46016, Ukraine, tanchik454@gmail.com

Oleksandra Kashuba is a Lecturer of Foreign Language at Ternopil V. Hnatiuk National Pedagogical University, Ukraine. She got her PhD (Candidate of Pedagogical Sciences). Her scientific interests are higher education, foreign language teaching methods, German as a Second Language. ORCID ID: https://orcid.org/0000-0002-5478-2875

Kashuba Oleksandra (0000-0002-5478-2875) orcid.org

Pushkina str. 5/90, Ternopil, 46016, Ukraine lesiakashuba@gmail.com

Halyna Navolska is a Lecturer of Foreign Language at Ternopil V. Hnatiuk National Pedagogical University, Ukraine. She got her PhD (Candidate of Pedagogical Sciences). Her scientific interests are higher education, foreign language teaching methods, Latin as a Second Language. ORCID ID: https://orcid.org/0000-0003-4196-0123

Halyna Navolska (0000-0003-4196-0123) orcid.org Vilhova str. 27/12, Ternopil, 46003, Ukraine, navolska9@gmail.com

Ivan Kutsyi is a Lecturer of Faculty of History at Ternopil V. Hnatiuk National Pedagogical University, Ukraine. Doctor of Historical Sciences, Professor. His scientific interests are Ukrainian national movement, historiography, civilizational identity.

ORCID ID: https://orcid.org/0000-0002-3556-1962

Ivan Kutsyi (0000-0002-3556-1962) orcid.org

Berezhanska str. 55/44, Ternopil, 46027, Ukraine kutsyy@ ukr.net

\section{References}

ANNEX (2018). to the Proposal for a Council Recommendation on Key Competences for Lifelong Learning. Brussels. Retrieved from https://ec.europa.eu/education/sites/education/files/annex-recommendation-keycompetences-lifelong-learning.pdf.

Barton, R., \& Haydn, T. (2006). Opinions of instructors-trainees on what helps them to use informational technologies in field study in an effective way. Zhurnal kompuiternoho obucheniia, 22, 257-272.

Beh, I. (1998). Student-centered upbringing. Kyiv: Lybid, Ukraine. 
Bespalko, V. P. (1968). Experience in developing and applying evaluation criteria for knowledge acquisition. Sovetskaja pedagogika, 4, 52-59.

Bibik, N. M. (2017). New Ukrainian school: A guide for teachers. Kyiv: Publishing House "Pleyady," Ukraine.

Bodnar, S. (2007). Analysis of terms "competence" and "competency" in pedagogics: essence and structure. Osvita I upravlinnia, 2, 93-99.

Chomsky, N. (1972). Language and thinking. B.Yu. Gorodetsky. Moscow: Moscow State

University, Russia.

Cronbach, L. J. (1951). Coefficient alpha and the internal structure of tests. Psychometrika, 16 (3), 297-334. Doi: 10.1007/bf02310555.

Fedorenko, Yu. S. (2002). Communicative competence as the most crucial element of successful communication. Rina shkola, 1, 63-65.

Grammar Way. (2016). Грамматика английского языка [English grammar]. Available at https://grammarway.com/ru

Hez, N. (1985). Formation of communicative competence as the object of foreign methodological research. Inostrannyi yazyki $v$ shkolie, 2(1), 7-24.

Hryshchuk, Y. V. (2014). International academic mobility in Ukraine: problems and prospects. Sociological Discourse, 2 (6), 33-40.

Hymes, Dell (1966). Two types of linguistic relativity. In W. Bright, (ed.), Sociolinguistics (pp. 114-158). The Hague: Mouton.

Izarenkov, D. I. (1990). Essential components of communicative competence and their formation at the advanced stage of training of students of non-philological specialties. Russkii yazyk za rubezhom, 4, 54-60.

Kazartseva, O. (1999). Culture of speech communication: Theory and practice. Moscow: Flint:

Nauka, Russia.

Lomakovytch, S., Tereschenko, V., Lukianchuk T., \& Korniichuk V. (2011). Verbal-

communicative competence a person: dimensions and measurements. Visnyk.

Testuvannia i monitorynh v osviti, 1, 4-1.

Quizlet (2021). Speak Out Elementary Unit 2. Available at https:/quizlet.com/217872576/speakout-elementary-unit-2-flash-cards/

Savignon, S. (1995). Evolution of Communicative Competence: The ACTFL Provisional Proficiency Guidelines.The Modern Language Journal, 95, 129-134.

SpeakOut. Retrieved at https://quizlet.com/217872576/speakout-elementary-unit-2-flash-cards/

Vatuitniev, M. (1977). Communicativeness of teaching Russian in schools abroad. Russkii yazyk za rubezhom, 6, 38-45. 